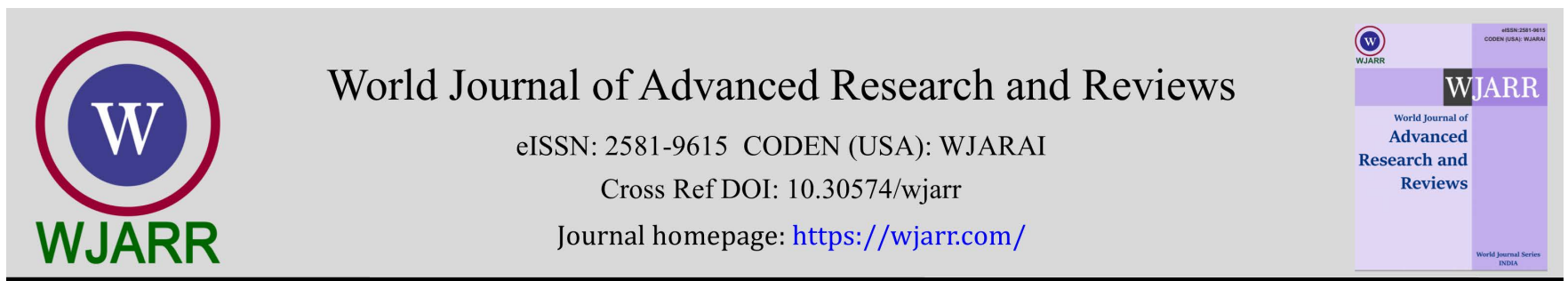

(RESEARCH ARTiClE)

\title{
The Beliefs of Physiotherapy, Occupational Therapy, and Speech and Language Therapy undergraduate students about learning English Language.
}

\author{
Akhi Akter, Asma Islam * and Nure Naznin \\ Bangladesh Health Professions Institute- Affiliated to the University of Dhaka, Dhaka, Bangladesh.
}

World Journal of Advanced Research and Reviews, 2022, 13(01), 576-582

Publication history: Received on 12 December 2021; revised on 19 January 2022; accepted on 21 January 2022

Article DOI: https://doi.org/10.30574/wjarr.2022.13.1.0060

\begin{abstract}
The current study was aimed to explore the existing beliefs about learning English language of the medical students who are mainly involved in rehabilitation studies such as Physiotherapy, Occupational therapy, and Speech and Language Therapy in a renowned Health professional's institute of Bangladesh. A mixed method: Quantitative and thematic analysis were selected for this study. A convenient sampling technique was used to select the sample. An EQuestionnaire was developed using Google form along with the original traditional version of the Questionnaire. "Beliefs about Language Learning Inventory (BALLI)" Questionnaire was used to find out the belief of students. A descriptive statistical analysis was conducted through IBM SPSS Statistics version 20 and presented in table. Later the finding was discussed under 5 themes: Motivation and expectation of learning English, Aptitude, Preferred strategies of learning English, Values of learning English and Easiness of learning English. Finally, some recommendations came from the students regarding the improvement of the Quality of English education.
\end{abstract}

Keywords: Beliefs; Learner; English language; Foreign language

\section{Introduction}

English language is the most common language worldwide where any country in the world will be hardly found without practicing this language in the academic sectors. It is said to be the most spoken language across the world where every 1 in 5 persons can understand, 380 native speakers 300 million users as a second language and 100 million as foreign languages [1]. Bangladesh is a highly densely populated country and there is a significant portion of the population learning and practicing English as a foreign language (EFL) or English as a second language (ESL). When English is used extensively in every aspect and everywhere in a country such as in parliament or public places along with the state language, it is called the second language. On the other hand, when English is mostly used for the academic purpose, it is termed as a foreign language. In Bangladesh, English language is staying in between second and foreign language. However, English has got the status of the second language in this country because it is the only recognized language besides Bangla language [2]. In Bangladesh, formal and institutional English education started in British time. After 1971 the government tried to establish Bangla more strongly by replacing English. The strategy didn't work because most of the books on higher education didn't have the Bangla version. Nowadays English is established to the major/non-major courses in honors programs in different public and private universities [3]. As English is now considered the global medium of communication people are more interested to learn English. But most of the time they face so many challenges due to the diverse background of the learners. Common challenges include inconsistent behavior of learners, lack of vocabulary, different phonological approach, affective factors, and many more [4]. The role of affective factors in learning a different language has been discussing since the 1980s. Those factors include attitudes, motivations, anxieties, and beliefs. Many researchers believe that these factors are very important to consider while learning a different language [5]. Among these affective factors, very few studies have focused on learner's beliefs

\footnotetext{
${ }^{*}$ Corresponding author: Asma Islam

Bangladesh Health Professions Institute- Affiliated to the University of Dhaka, Dhaka, Bangladesh.

Copyright (C) 2022 Author(s) retain the copyright of this article. This article is published under the terms of the Creative Commons Attribution Liscense 4.0.
} 
toward learning a different language. Beliefs refer to the personal and subjective understanding of an individual regarding a certain issue and often it is difficult to change. In the case of an adult, beliefs force the process of learning significantly [6]. Some other studies also explored few other affective factors in different countries. A study found that students are reluctant toward learning English and interact in English, teachers are playing a very dominant role rather interactive, lack of teacher-student good relationship, lack of teaching materials in a Russian university and another in an Iranian university. The researchers recommended having more interactive class sessions through group studies and to make the class livelier [7]. A Pakistani researcher recommended the possible solution which includes language planners, policymakers', linguists, and practitioners who need to face the challenge and provide practical language policies and proper implementation of those policies [8]. Another study found that in South Africa majority of university students are unable to communicate properly in English because the language courses are irrelevant to practical, classroom education is mostly teacher-centered which mostly priorities African language (Zulu) rather than practicing in English. The author believes that the students need opportunities to practice and enough class materials to have effective language learning [9]. So, from the light of the pieces of literature, the current study was aimed to explore the existing beliefs about learning the English language of the medical students who are mainly involved in rehabilitation studies such as physiotherapy, Occupational therapy, and Speech and Language Therapy in a Health professional's institute of Bangladesh.

\section{Material and methods}

A cross sectional design was selected for this study. Study Population was identified from the current students of 1 st year to $4^{\text {th }}$ year Physiotherapy, Occupational therapy and Speech and Language therapy of Bangladesh health Professions Institute (BHPI), CRP. The study includes only those who have completed the English foundation course of BHPI. A convenient sampling technique was used to select the sample. An E-Questionnaire was developed using Google form along with the original traditional version of the Questionnaire. The Questionnaire had two parts. The first part contained self-structured part where the basic questions were asked such as name, age, socio-economic status etc. The second part contained "Beliefs about Language Learning Inventory (BALLI)" which was used to find out the belief of students. It is a valid, reliable, easy administrable tool which assesses student beliefs in five areas: 1) difficulty of language learning; 2) foreign language aptitude; 3) the nature of language learning; 4) learning and communication strategies; and 5) motivations and expectations [10]. Study duration was July 2021 to November 2021. An Ethical approval was taken from the Institutional Review board (CRP/ BHPI/IRB/ 07/2021/489) and the Data collection approval was taken from the Principal of BHPI. A written consent was taken from every participant. Only interested students were taken. They were assured that all the information will be kept confidential. Their participation will not cause any positive or negative effect on their academic career. They also were informed that they can withdraw their participation at any time. The participants were informed about the aim and objective of the study prior to participation. The responses of the participants were evaluated carefully. A descriptive statistical analysis was conducted through IBM SPSS Statistics version 20 and presented in table. Later the finding was discussed under 5 themes: Motivation and expectation of learning English, Aptitude, Preferred strategies of learning English, Values of learning English and Easiness of learning English. Finally, some recommendations came from the students regarding the improvement the Quality of English education.

\section{Results and discussion}

The study was aimed to find out the existing belief of Physiotherapy, Occupational therapy, and Speech and Language therapy undergraduate students about learning English Language. 411 participants were selected conveniently who are currently studying at BHPI. Among The participants $(n=411)$ male was $41 \%$ and female was $59 \%$. Mean age of the participants was 21 . Physiotherapy, Occupational therapy and speech language therapy students were $52 \%, 18 \%$ and $30 \%$ respectively. $1^{\text {st }}$ year students were found more interested $(44 \%)$ to participate into the study where the $2^{\text {nd }}, 3^{\text {rd }}$ and $4^{\text {th }}$ also took part $(19 \%, 23 \% .14 \%)$ respectively. SSC mean GPA was found 4.91 and HSC mean GPA was 4.56. Most of the participants belong to middle class society (95\%).

The existing belief of the students about learning English language was identified using 33 items of beliefs about Language Learning Inventory (BALLI) Questionnaire. Question 1 to Question 31 answers were evaluated in a Likert scale. The total responses were tabulated including frequency, percentage, mean and standard deviation of the responses. The analysis was further divided in few themes emerged from the Questions and discussed in paragraph. The themes are: Motivation and expectation of learning English - item 3, 5, 8, 13, 21 and 31. Aptitude 16, 19 and 23. Preferred strategies of learning English item 4, 6, 7, 9, 17, 21, 28 and 30. Values of learning English item 10, 11, 12, 14, 20, 22, 24, 25, 27, 29, 31 and 33. Easiness of learning English item 1, 2, 15, 18, and 26. 
Table 1 Baseline information of participants

\begin{tabular}{|l|l|l|}
\hline Variables & Frequency and Percentage (n=411) & Mean/SD (n=411) \\
\hline Age of Participants & & $21 / 1.682$ \\
\hline Gender & $\begin{array}{l}\text { Male: } 170(41 \%) \\
\text { Female: } 241(59 \%)\end{array}$ & \\
\hline Program/course & $\begin{array}{l}\text { Physiotherapy: } 215(52 \%) \\
\text { Occupational therapy: } 74(18 \%) \\
\text { Speech and language therapy 122(30\%) }\end{array}$ & \\
\hline Current Year of study & $\begin{array}{l}1^{\text {st }} \text { year: } 181(44 \%) \\
2^{\text {nd }} \text { year: } 76(19 \%) \\
3^{\text {rd }} \text { year: } 95(23 \%) \\
4^{\text {th }} \text { year: } 59(14 \%)\end{array}$ & $4.91 / 0.196$ \\
\hline GPA- SSC & & $4.56 / 0.420$ \\
\hline GPA- HSC & Upper class: 2 & \\
\hline Socio-Economic Status (SES) & $\begin{array}{l}\text { Middle class: } 95 \\
\text { Lower class: } 3\end{array}$ & \\
\hline
\end{tabular}

Table 2 Descriptive analysis (frequency, mean and standard deviation) of Beliefs about Language Learning Inventory (BALLI) from Q 1 to $Q 31$

\begin{tabular}{|l|c|c|c|c|c|c|c|}
\hline Item & SA\% & A\% & UD\% & D\% & SD\% & Mean & $\begin{array}{c}\text { Standard } \\
\text { Deviation }\end{array}$ \\
\hline $\begin{array}{l}\text { 1. It is easier for children than adults to learn a } \\
\text { foreign language. }\end{array}$ & 22 & 64 & 4 & 10 & 0 & 2.01 & 0.810 \\
\hline 2.Some languages are easier than others & 11 & 75 & 8 & 6 & 0 & 2.10 & 0.662 \\
\hline $\begin{array}{l}\text { 3. If I get to speak this language very well, I will have } \\
\text { many opportunities to use it. }\end{array}$ & 43 & 54 & 2 & 1 & 0 & 1.60 & 0.577 \\
\hline 4. It is important to repeat and practice a lot & 58 & 40 & 2 & 0 & 0 & 1.44 & 0.539 \\
\hline $\begin{array}{l}\text { 5. I would like to learn this language so that I can get } \\
\text { to know its speakers better. }\end{array}$ & 30 & 63 & 5 & 2 & 0 & 1.80 & 0.638 \\
\hline $\begin{array}{l}\text { 6. It's okay to guess if you don't know a word in a } \\
\text { foreign language. }\end{array}$ & 4 & 47 & 20 & 27 & 2 & 2.75 & 0.955 \\
\hline $\begin{array}{l}\text { 7. Learning a foreign language is mostly a matter of } \\
\text { translating. }\end{array}$ & 12 & 61 & 13 & 13 & 1 & 2.31 & 0.886 \\
\hline $\begin{array}{l}\text { 8. I believe that I will ultimately learn to speak this } \\
\text { language very well. }\end{array}$ & 24 & 64 & 8 & 4 & 0 & 1.92 & 0.683 \\
\hline $\begin{array}{l}\text { 9. Learning a foreign language is mostly a matter of } \\
\text { learning a lot of new vocabulary words. }\end{array}$ & 38 & 55 & 5 & 2 & 0 & 1.71 & 0.667 \\
\hline $\begin{array}{l}\text { 10. It is easier to read and write this language than } \\
\text { to speak and understand it. }\end{array}$ & 20 & 56 & 9 & 14 & 1 & 2.19 & 0.933 \\
\hline $\begin{array}{l}\text { 11. Women are better than men at learning foreign } \\
\text { languages. }\end{array}$ & 5 & 19 & 44 & 26 & 6 & 3.09 & 0.945 \\
\hline $\begin{array}{l}\text { 12. It is important to speak a foreign language with } \\
\text { an excellent accent. }\end{array}$ & 16 & 55 & 10 & 18 & 1 & 2.34 & 0.615 \\
\hline
\end{tabular}




\begin{tabular}{|c|c|c|c|c|c|c|c|}
\hline $\begin{array}{l}\text { 13. If I learn to speak this language very well, it will } \\
\text { help me get a good job. }\end{array}$ & 42 & 53 & 3 & 2 & 0 & 1.64 & 0.615 \\
\hline $\begin{array}{l}\text { 14. You shouldn't say anything in a foreign language } \\
\text { until you can say it correctly. }\end{array}$ & 11 & 45 & 10 & 30 & 4 & 2.72 & 1.141 \\
\hline $\begin{array}{l}\text { 15. It is easier to speak than to understand a foreign } \\
\text { language. }\end{array}$ & 6 & 40 & 14 & 38 & 2 & 2.90 & 1.058 \\
\hline $\begin{array}{l}\text { 16. Some people are born with a special ability } \\
\text { which helps them learn a foreign language. }\end{array}$ & 7 & 42 & 21 & 25 & 5 & 2.77 & 1.052 \\
\hline $\begin{array}{l}\text { 17. Learning a foreign language is mostly a matter } \\
\text { of learning a lot of grammar rules. }\end{array}$ & 9 & 48 & 9 & 29 & 5 & 2.71 & 1.118 \\
\hline $\begin{array}{l}\text { 18. It is easier to speak than to understand a foreign } \\
\text { language. }\end{array}$ & 6 & 39 & 14 & 39 & 2 & 2.92 & 1.051 \\
\hline $\begin{array}{l}\text { 19. It is easier for someone who already speaks a } \\
\text { foreign language to learn another one. }\end{array}$ & 7 & 56 & 21 & 15 & 1 & 2.48 & 0.859 \\
\hline $\begin{array}{l}\text { 20. New Zealanders think that it is important to } \\
\text { speak a foreign language. }\end{array}$ & 6 & 46 & 41 & 7 & 0 & 2.50 & 0.717 \\
\hline $\begin{array}{l}\text { 21. If I heard someone speaking in the language I am } \\
\text { trying to learn; I would go up to them so that I could } \\
\text { practice speaking the language. }\end{array}$ & 14 & 68 & 13 & 4 & 1 & 2.08 & 0.691 \\
\hline $\begin{array}{l}\text { 22. People who are good at math and science are not } \\
\text { good at learning foreign languages. }\end{array}$ & 3 & 24 & 16 & 47 & 10 & 3.36 & 1.051 \\
\hline 23. I have foreign language aptitude. & 8 & 52 & 25 & 14 & 1 & 2.50 & 0.876 \\
\hline $\begin{array}{l}\text { 24. It is necessary to know the foreign culture in } \\
\text { order to speak the foreign language. }\end{array}$ & 6 & 44 & 17 & 30 & 3 & 2.78 & 1.024 \\
\hline $\begin{array}{l}\text { 25. Learning a foreign language is different from } \\
\text { learning other school subjects. }\end{array}$ & 8 & 64 & 12 & 15 & 1 & 2.38 & 0.882 \\
\hline $\begin{array}{l}\text { 26. New Zealanders (Bangladeshi) are good at } \\
\text { learning foreign languages. }\end{array}$ & 3 & 38 & 50 & 8 & 1 & 2.64 & 0.6696 \\
\hline $\begin{array}{l}\text { 27. I feel self-conscious speaking the foreign } \\
\text { language in front of other people. }\end{array}$ & 10 & 66 & 16 & 7 & 1 & 2.23 & 0.760 \\
\hline $\begin{array}{l}\text { 28. If you are allowed to make mistakes in the } \\
\text { beginning it will be hard to get rid of them later on. }\end{array}$ & 8 & 45 & 14 & 31 & 2 & 2.74 & 1.053 \\
\hline $\begin{array}{l}\text { 29. People who speak more than one language well } \\
\text { are very intelligent. }\end{array}$ & 8 & 56 & 19 & 16 & 1 & 2.45 & 0.889 \\
\hline $\begin{array}{l}\text { 30. It is better to learn the foreign language in the } \\
\text { foreign country. }\end{array}$ & 10 & 47 & 15 & 25 & 3 & 2.64 & 1.047 \\
\hline 31. Everyone can learn to speak a foreign language & 17 & 64 & 7 & 11 & 1 & 2.16 & 0.861 \\
\hline
\end{tabular}

SA= strongly agree (1), A-agree (2), UD- Undecided (3), D-Disagree (4), SD- Strongly disagree (5)

Table 3 Descriptive analysis of Beliefs about Language Learning Inventory (BALLI) - Q 32

\begin{tabular}{|l|c|c|c|c|c|l|l|}
\hline Item & $\begin{array}{l}\text { a very } \\
\text { difficult } \\
\text { language }\end{array}$ & $\begin{array}{l}\text { a difficult } \\
\text { language }\end{array}$ & $\begin{array}{l}\text { language of } \\
\text { medium } \\
\text { difficulty }\end{array}$ & $\begin{array}{l}\text { an easy } \\
\text { language }\end{array}$ & $\begin{array}{l}\text { a very easy } \\
\text { language }\end{array}$ & $\begin{array}{l}\text { Mea } \\
\text { n }\end{array}$ & SD \\
\hline $\begin{array}{l}\text { 32. The language I am } \\
\text { trying to learn is }\end{array}$ & 3 & 27 & 50 & 16 & 4 & 2.92 & 0.828 \\
\hline
\end{tabular}


Table 4 Descriptive analysis of Beliefs about Language Learning Inventory (BALLI) - Q 33

\begin{tabular}{|l|l|c|c|c|c|c|c|}
\hline Item & $\begin{array}{l}\text { Less than } \\
\text { a year }\end{array}$ & $\begin{array}{l}\mathbf{1 - 2} \\
\text { years }\end{array}$ & $\begin{array}{l}\mathbf{3 - 5} \\
\text { years }\end{array}$ & $\begin{array}{c}\mathbf{5 - 1 0} \\
\text { years }\end{array}$ & $\begin{array}{l}\text { Can't learn } \\
\text { in one } \\
\text { hour a day }\end{array}$ & Mean & SD \\
\hline $\begin{array}{l}\text { 33. If someone spent one hour a day } \\
\text { learning this language, how long } \\
\text { would it take him/her to become } \\
\text { fluent? }\end{array}$ & 52 & 33 & 5 & 1 & 9 & 1.81 & 1.167 \\
\hline
\end{tabular}

\subsection{Motivation and expectation of learning English}

97\% of participant strongly agreed to agree that learning English language will bring many opportunities to use it for them. Most of them (93\% are agreed to strongly agreed) that they would like to learn this language so that they can get to know its speakers better.95\% of the participant believes that speaking good English will help them to get good job. They have a strong belief (81\%) that everyone can learn to speak a foreign language.

\subsection{Aptitude}

Aptitude is the natural ability to do something. About half (49\%) of the participant believe that some people are born with a special ability which helps them learn a foreign language. At the same time $30 \%$ disagreed with the statement while $21 \%$ could not decide their believe regarding this area. Most of them believe that learning English language is easier for someone who already speaks a foreign language. Few of them in fact disagreed with the statement. 52\% claimed that they have foreign language aptitude. Among the residuals few of them couldn't decide and disagreed.

\subsection{Preferred strategies of learning English}

About 98\% participants expressed their agreement that practice and repetition is important for learning English. Many of them believe that learning a foreign language is by translating. Some of them think that if someone don't know the correct word in foreign language it is sufficient to guess the word and apply. But many of them also confused and disagree the statement. $93 \%$ participants admit that learning a foreign language is mostly a matter of learning a lot of new vocabulary words. About 57\% thinks that learning a lot of grammatical rules is important to learn a foreign language while some other (34\%) were disagreed and confused (9\%) about the statement. About half of the participants believe that it is important to learn correctly from the beginning. They think that if someone is allowed to make mistakes in the beginning it will be hard to get rid of them later on. The other half is confused and not agreed with the situation. About half of them considered that it is better to learn the foreign language in the foreign country while another half don't think so. Most of them preferred to practice with someone who speaks English.

\subsection{Values of learning English}

The participants possess different values of learning English. 76\% found reading and writing is easier than speaking and understanding English. Few of them admit that women are better than men at learning foreign languages while few disagreed. Many of them (44\%) are confused about the gender issue of learning foreign language. Most of them (71\%) give importance to speak a foreign language with an excellent accent. Half of them give emphasize on correctly speaking. They believe that someone shouldn't say anything in a foreign language until he or she can say it correctly. But the other half disagree and confused about the statement. Besides, half of them think that it is important to speak a foreign language while another half disagreed and couldn't decide what to do. Very few of them (27\%) believe that people who are good at math and science are not good at learning foreign languages while most of them disagreed. $50 \%$ of them think that it is necessary to know the foreign culture in order to speak the foreign language while the other don't think so.

\subsection{Easiness of learning English}

Most of them believe leaning English is not similar to learning other subjects in school. They also think people who speak more than one language well are very intelligent. $50 \%$ of them identified English as medium difficulties while $30 \%$ told it's very difficult or difficult. Very few (20\%) identified it as easy and very easy. If someone spent one hour a day learning this language, 52\% think it would take less than 1 year to learn and to become fluent, $33 \%$ think 1 to 2 years, $1 \%$ is 5 to 10 years and $9 \%$ think one hour is not sufficient to learn. 


\subsection{Recommendation from students}

Besides the existing belief, students were asked to provide their recommendation regarding the current English program offered by BHPI. Several constructive recommendations came out. Most of them told that it is very important to have extensive practice in order to learn good English specially in writing part. They claimed that if they have opportunities to have practical application of English that will help a lot such as English communication with English native speakers, journal writing, and English presentation. They emphasized on the environmental modification such as improvement of teaching material especially the audiovisual media, improve the learning facilities. They want more cooperation and motivation from teachers toward learning English. They mentioned that different programmes in English such as IELTS, Debate sessions can enrich the existing English module.

The study aim was to identify the belief of the undergraduate rehabilitation profession students toward learning English. The students were identified from a renowned Health Professions Institute of Bangladesh which is affiliated to the University of Dhaka, Bangladesh.

These students have to study in English medium therefore there is a compulsory English subject which has been designed mainly focusing on the academic writing and understanding purpose. Most of the undergraduate participants' age range was between 21 to 25. Most of the participants are from middle class society. In Bangladesh around 22\% population belong to middle class society [11]. There are about one hundred and forty privately funded university in Bangladesh where mostly the upper and middle class study [12]. In our study there is similarity as well dissimilarity exists. Most of our participants are female (59\%). In Bangladesh female in higher education is expanding [13]. In fact, now a days women are playing leading role within higher education in Bangladesh [14]. We have found that most of the participants strongly believe that learning English will bring more opportunities for them and they will be able to understand the English speakers very well. They also think that it will help them to get good job. A similar study found international orientation as an important motivation and expectation for learning English in the Japanese context [15]. Most of our participants believe that learning English will help them to get good job and help them to know the English language speakers better. Similar study found that Learning English is important if someone wants to come up in life. They also claimed that English is the major window or entrance for technically qualified person to the advanced world countries [16]. Majority of the participants believe that some people have natural ability to learn English especially who speaks foreign or English language. A study explored that aptitude has a great impact on human cognitive abilities and their learning process [17]. This study found that most of the participants gave priority on practicing English especially with native speakers. They think that learning English is learning vocabulary, a lot of translation and grammar rules. Another similar study identified few preferred strategies of learning English of high school students. Those are, improvement of skill through practice, learn many vocabularies and structures, writing with standard procedure [18]. In the current study, students think that reading and writing is easier than speaking and understanding English. They also think that women learn English better than men. They said, it is better to speak correctly otherwise not. Some of them believe that those who are good at math and science are not good at learning foreign languages. They recommended to have better practical application such as academic writing, presentation and Journal publication. They think that the improvement of learning environment can also have positive impact on learning English. A study recommends that well equipped class room, financial reward, conductive learning environment of the institution, motivated and trained teachers are crucial for learning any foreign language [19]

\section{Conclusion}

The current study successfully explored the different affective factors of learning English which have been discussed earlier. Many constructive recommendations came out in order to enrich the existing learning system. The concern Institute and the global scholars in this area can consider these issues and work in it in future.

\section{Compliance with ethical standards}

\section{Acknowledgments}

An acknowledgement goes to the BHPI authority who helped to conduct the study.

\section{Disclosure of conflict of interest}

The Authors declares no conflict of Interest. 


\section{Statement of ethical approval}

An Ethical approval was taken from the Institutional Review board (CRP/ BHPI/IRB/ 07/2021/489) and the Data collection approval was taken from the Principal of BHPI.

\section{Statement of informed consent}

Written Informed consent was obtained from all individual participants included in the study.

\section{References}

[1] Rahman MM, Pandian A. A critical investigation of English language teaching in Bangladesh: Unfulfilled expectations after two decades of communicative language teaching. English Today. Sep 2018; 34(3): 43-9.

[2] Rubel HM. Development of English Language Teaching In Bangladeshi Universities: Context, Problems and Implications. International Journal of Advanced Research and Publications. 2019; 3(1).

[3] Rasheed M. Learning English language in Bangladesh: CLT and beyond. Critical literacy: theories and practices. 2012; 6(2): 31-49.

[4] Ellis R, Ellis RR. The study of second language acquisition. Oxford University. 1994.

[5] Alexander PA, Dochy FJ. Conceptions of knowledge and beliefs: A comparison across varying cultural and educational communities. American Educational Research Journal. Jun 1995; 32(2): 413-42.

[6] Mahu DP. Why Is Learning English So Beneficial Nowadays? International Journal of Communication Research. 1 Oct 2012; 2(4): 374 .

[7] Rubel HM. Development of English Language Teaching In Bangladeshi Universities: Context, Problems and Implications. International Journal of Advanced Research and Publications. 2019; 3(1).

[8] Jahan Khan T, Murad Sani A, Shaik Abdullah S. Exploration of instrumental and integrative motivation for reading English as a second language among second year pre-university students of government MAO college, Lahore (Pakistan). Open Journal of Social Sciences. 2016; 4(04): 69-76.

[9] Webb V. English in Higher Education in South Africa: inclusion or exclusion. InMultilingualism and Information Development Program (MIDP) symposium on Multilingualism and Exclusion, Bloemfontein. Apr 2006; 24-27.

[10] Horwitz EK. The beliefs about language learning of beginning university foreign language students. The modern language journal. 1 Oct 1988; 72(3): 283-94.

[11] Rahman MM. Country report: Bangladesh, ADBI-APO Workshop on Climate Change and its Impact on Agriculture.

[12] Islam N. Note from the Editor: Middle Class in Bangladesh. Bangladesh e-Journal of Sociology. 2017; 14(1): 4-15.

[13] Woman in Higher Education in Bangladesh.

[14] Ahad LR, Gunter H. Women in leader roles within higher education in Bangladesh. Management in Education. Jul 2017; 31(3): 135-40.

[15] Goharimehr N. Identity, motivation and English learning in a Japanese context. World. 2017; 7(4).

[16] Nishanthi R. The importance of learning English in today world. International Journal of Trend in Scientific Research and Development. 2018; 3(1): 871-4.

[17] Kocić A. The effects of aptitude on language learning. Komun. Kult. 2010; 1: 234-43.

[18] Ras F. PREFERRED STRATEGIES USED BY PEKANBARU SENIOR HIGH SCHOOL STUDENT'TO LEARN INDIVIDUAL SKILLS OF ENGLISH. Jurnal Nuances. 1 Nov 2012; 3(1): 1-7.

[19] Hussain MS, Salam A, Farid A. Students' Motivation in English Language Learning (ELL): An Exploratory Study of Motivation-al Factors for EFL and ESL Adult Learners. International Journal of Applied Linguistics and English Literature. 31 Jul 2020; 9(4):15-28. 